\title{
HUBUNGAN KEMAMPUAN MENYUSUN KALIMAT EFEKTIF DENGAN KEMAMPUAN MENULIS WACANA EKSPOSISI SISWA KELAS X SMA NEGERI 1 LAWE ALAS TAHUN PEMBELAJARAN 2016-2017
}

\section{Oleh:}

\author{
Ati Rosmiati / NIDN 1315108801 \\ STKIP Usman Syarif Kutacane
}

\begin{abstract}
Abstrak
Penelitian deskriptif korelasional bertujuan untuk melihat hubungan antara dua gejala atau lebih, dan cocok dengan permasalahan. Berdasarkan hasil penelitian dan pembahasan yang telah diuraikan pada bab terdahulu maka dapat disimpulkan bahwa ada hubungan positif antara kemampuan menyusun kalimat efektif dengan kemampuan menulis wacana eksposisi siswa kelas X SMA Negeri 1 Lawe Alas Tahun Pembelajaran 2016-2017. Hal ini terbukti dari nilai rata-rata tes awal 45,19 dan termasuk dalam kategori kurang, standar deviasi hubungan positif antara kemampuan menyusun kalimat efektif dengan kemampuan menulis wacana eksposisi siswa sebelum diberikan pembelajaran 13,68 dan mengalami peningkatan nilai hasil tes akhir sesudah diberikan pembelajaran adalah sebesar 80,72 dantermasuk dalam kategori baik. Selain itu, dari tabel diatas diperoleh hasil $t_{\text {hitung }}=19,70$, selanjutnya dikonsultasikan dengan nilai $\mathrm{t}_{\text {tabel }}$ pada taraf signifikan $5 \%$ dengan $\mathrm{db}=\mathrm{N}-1=36-$ $1=35$, maka diperoleh nilai $t_{\text {tabel }}=2,03$. Jadi dengan demikian nilai $t_{\text {hitung }} t_{\text {tabel }}$ atau diperoleh kesimpulan bahwa ada Hubungan Kemampuan Menyususn Kalimat Efektif Dengan Kemampuan Menulis Wacana Eksposisi Siswa Kelas X SMA Negeri 1 Lawe Alas Tahun Pembelajaran 2016-2017.
\end{abstract}

Kata Kunci : Kalimat Efektif, Menulis Wacana Eksposisi

\section{PENDAHULUAN}

Berdasarkan hasil observasi yang penulis lakukan di kelas $\mathrm{X}$

SMA Negeri 1 Lawe Alas, masih banyak terdapat siswa yang kurang mampu dan memahami tentang kalimat efektif dan kemampuan menulis wacana eksposisi, ini dikarenakan kurangnya motivasi dan kemampuan siswa dalam menuangkan gagasan atau ide. Idenya dalam sebuah karya tulis disamping itu, penggunaan metode pembelajaran selama ini masih bersifat monoton (membosankan) sehingga siswa tidak dapat 
mengembangkan kreativitas siswa khususnya menulis dan menyusun Kalimat efektif. Mengingat besarnya manfaat dan peranan kemampuan menulis wacana eksposisi dalam kehidupan seharihari, maka penelitian berupa hubungan kemampuan menyusun kalimat efektif dengan kemampuan menulis wacana eksposisi lebih digalakkan sebab minat siswa dalam memahami hubungan kalimat efektif dengan menulis wacana masih sangat kurang. Bertitik tolak dari uraian di atas maka penulis tertarik mengadakan penelitian dengan judul "Hubungan Kemampuan Menyusun Kalimat Efektif dengan Kemampuan Menulis Wacana Eksposisi Siswa Kelas X SMA Negeri 1 Lawe Alas Tahun Pembelajaran 2016-2017.

\section{PEMBAHASAN}

Kalimat efektif ialah bahasa yang dirasakan hidup, segar mudah ditangkap dan dipahami, yang secara tepat melahirkan gagasan yang sama tepatnya dalam pemikiran pembaca dan pendengar (Keraf, 2001:34). Setiap kalimat yang kita susun baik dalam bentuk usan maupun tulisan dapat kita nilai apakah efektif atau tidak. Untuk menilainya dapat kita kembalikan pada cirri-ciri sebagai berikut:

1. Kalimatnya disusun sesuai dengan struktur kalimat bahasa I ndonesia baku atau standar.

2. Pemilihan katanya tepat untuk menggambarkan konsep yang dimaksud oleh penulis.

3. Terhindar dari kalimat yang panjang dan bertele-tele.

4. Kesatuan pikiran yang terkandung didalamnya harus dapat dipahami dengan mudah.

5. Supaya bahasa menjadi hidup harus ada variasi misalnya, pilihan kata, gaya bahasa, kalimat dan panjang kalimat. Semi (2007: 14) dalam bukunya mengungkapkan pengertian menulis adalah suatu proses kreatif memindahkan gagasan ke dalam lambang-lambang tulisan. Burhan Nurgiantoro (1988: 273) menyatakan bahwa menulis adalah aktivitas aktif produktif, yaitu aktivitas menghasilkan bahasa.

$\begin{array}{rrr} & \text { Wacana } & \text { eksposisi adalah } \\ \text { satuan jenis } & \text { wacana yang }\end{array}$




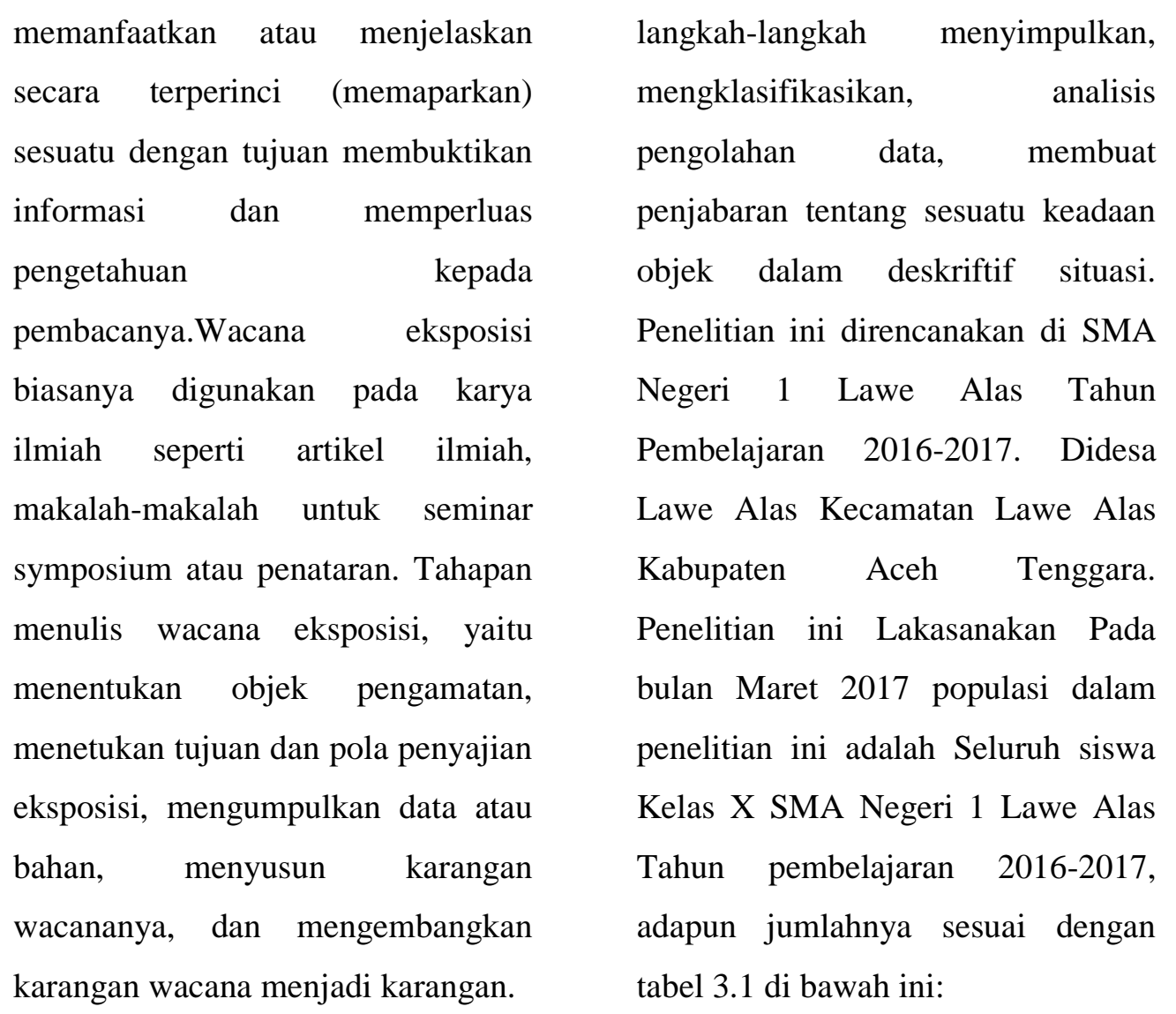

Tabel 3.1. Populasi

\section{METODE PENELITIAN}

Jenis penelitian ini
menggunakan metode penelitian
deskriptif korelasional bertujuan
melihat hubungan antara dua gejala
atau lebih, dan cocok dengan
permasalahan,
pemecahan masalah sesuai dengan
pendapat Sudjana (2005:190)
Menyatakan" Bahwa metode
deskriptif sering digunakan untuk
berupaya memecahkanmasalah yang
dihadapi pada situasi sekarang
dilakukan dengan menempuh

\begin{tabular}{|c|c|c|}
\hline NO & KELAS & POPULASI \\
\hline 1 & X.1 & 30 \\
2 & X.2 & 31 \\
3 & X.3 & 30 \\
4 & X.4 & 30 \\
\hline \multicolumn{2}{|c|}{ JUMLAH } & $\mathbf{1 2 1}$ \\
\hline
\end{tabular}

Pengambilan sampel dalam penelitian ini menggunakan sistem acak atau random sampling. Adapun banyaknya sampel dalam penelitian ini adalah 60 orang siswa yang diambil dari empat kelas yang ada, 
adapun

langkah-langkah

pengambilan sampel adalah:

1. Menentukan jumlah sampel berdasarkan persentase populasi, dalam penelitian ini diambil $30 \%$ dari total populasi 36,3 , atau dibulatkan menjadi 36 orang siswa.

2. Setiap kelas ditetapkan sampel 9 siswa

3. Pengambilan secara acak sederhana dapat menggunakan gulungan kertas, lalu diambil secara acak untuk mewakili setiap sampel.

Tabel 3.2 Sampel Penelitian

\begin{tabular}{|c|c|}
\hline Kelas & Sampel \\
\hline X.I & 9 Orang \\
X.2 & 9 Orang \\
X.3 & 9 Orang \\
X.4 & 9 Orang \\
& \\
\hline JUMLAH & $\mathbf{3 6}$ \\
& Orang \\
\hline
\end{tabular}

\section{HASIL PENELITAN}

Penelitian ini bertujuan untuk mengetahui Hubungan Kemampuan Menyususn Kalimat Efektif Dengan
Kemampuan Menulis Wacana Eksposisi Siswa Kelas X SMA Negeri 1 Lawe Alas Tahun Pembelajaran 2016-2017. Berikut ini adalah data hasil penelitian yang diperoleh dari hasil tes awal dan tes akhir siswa. Hasil analisis data penelitian yang diperoleh dari tes awal Kemampuan Menyususn Kalimat Efektif Dengan Kemampuan Menulis Wacana Eksposisi Siswa Kelas X SMA Negeri 1 Lawe Alas Tahun Pembelajaran 2016-2017. Adapun penyajian datanya dapat dilihat pada table 4.2 sebagai berikut:

Tabel 4.2. Hasil Tes Awal Menulis Wacana Eksposisi oleh Siswa

\begin{tabular}{|c|c|}
\hline Nilai Tes Awal & Frequency \\
\hline 26.00 & 5 \\
\hline 30.00 & 2 \\
\hline 33.00 & 6 \\
\hline 40.00 & 4 \\
\hline 50.00 & 5 \\
\hline 53.00 & 5 \\
\hline 60.00 & 5 \\
\hline 66.00 & 4 \\
\hline Total & 36 \\
\hline
\end{tabular}

Sumber : Analisis Data dengan SPSS 19 for windows 
Dari table 4.2 diatas nilai rata-rata, dan standar devisiasinya dapat dihitung menggunakan analisis spss 19 for windows sebagai berikut:

Tabel 4.3.Deskriptif Data Tes Awal Menulis Wacana Eksposisi oleh Siswa

\begin{tabular}{|l|r|r|r|r|r|}
\hline & & Mi & Ma & & Std. \\
& & ni & xi & M & Devi \\
& mu & mu & ea & atio \\
& m & m & n & n \\
\hline TES & 36 & 26. & 66. & 45 & 13.6 \\
AW & & 00 & 00 & .1 & 817 \\
AL & & & & 94 & 3 \\
Valid & 36 & & & & \\
N & & & & & \\
(listw & & & & & \\
ise) & & & & & \\
\hline
\end{tabular}

Sumber : Analisis Data dengan SPSS 19 for windows

a. Rata-rata Tes Awal

Dari table 4.3 diatas rata-rata Hubungan Kemampuan Menyususn Kalimat Efektif Dengan Kemampuan Menulis Wacana Eksposisi Siswa sebelum diberikan pembelajaran adalah sebesar
45,19 dan termasuk dalam kategori kurang.

b. Standar Devisiasi

Dari table 4.3 diatas standar devisiasi Hubungan Kemampuan Menyususn Kalimat Efektif Dengan Kemampuan Menulis Wacana Eksposisi Siswa sebelum diberikan pembelajaran adalah sebesar adalah 13,68

1. Deskripsi Data Tes Akhir Hubungan Kemampuan

Menyususn Kalimat Efektif Dengan Kemampuan Menulis Wacana Eksposisi Oleh Siswa Sesudah Diberikan Pembelajaran

Berikut ini adalah hasil analisis data penelitian yang diperoleh dari tes akhir Kemampuan Menyususn Kalimat Efektif Dengan Kemampuan Menulis Wacana Eksposisi Siswa Kelas X SMA Negeri 1 Lawe Alas Tahun Pembelajaran 2016-2017. Adapun 
penyajian datanya dapat dilihat pada table 4.4 sebagai berikut:

Tabel 4.4. Hasil Tes Akhir Menulis Wacana Eksposisi oleh

\begin{tabular}{|c|c|}
\hline \multicolumn{2}{|c}{ Siswa } \\
\hline Nilai Tes Akhir & Frequency \\
\hline 70.00 & 3 \\
\hline 73.00 & 3 \\
\hline 75.00 & 5 \\
\hline 80.00 & 8 \\
\hline 85.00 & 5 \\
\hline 86.00 & 7 \\
\hline 87.00 & 5 \\
\hline Total & 36 \\
\hline
\end{tabular}

Dari table 4.4 diatas nilai rata-rata, dan standar devisiasinya dapat dihitung menggunakan analisis spss 19 for windows sebagai berikut:

Tabel 4.5.Deskriptif Data Tes Akhir Menulis Wacana Eksposisi oleh Siswa

\begin{tabular}{|l|r|r|r|c|c|}
\hline & & $\begin{array}{r}\text { Mini } \\
\mathrm{mu}\end{array}$ & $\begin{array}{c}\text { Max } \\
\text { imu } \\
\mathrm{m}\end{array}$ & $\begin{array}{c}\text { Mea } \\
\mathrm{m}\end{array}$ & $\begin{array}{c}\text { Std. } \\
\text { Deviat } \\
\text { ion }\end{array}$ \\
\hline TES & 36 & 70.0 & 87.0 & 80.7 & 5.7946 \\
AKHIR & & 0 & 0 & 222 & 3 \\
\hline
\end{tabular}

\begin{tabular}{|l|r|r|r|r|r|}
\hline & & $\begin{array}{r}\text { Mini } \\
\mathrm{mu}\end{array}$ & $\begin{array}{c}\text { Max } \\
\text { imu }\end{array}$ & $\begin{array}{c}\text { Mea } \\
\mathrm{m}\end{array}$ & $\begin{array}{c}\text { Deviat } \\
\mathrm{m}\end{array}$ \\
$\mathrm{N}$ & $\mathrm{n}$ & $\mathrm{1}$ \\
\hline TES & 36 & 70.0 & 87.0 & 80.7 & 5.7946 \\
AKHIR & & 0 & 0 & 222 & 3 \\
Valid N & 36 & & & & \\
(listwis & & & & & \\
e) & & & & & \\
\hline
\end{tabular}

Sumber : Analisis Data dengan SPSS

$$
19 \text { for windows }
$$

a. Rata-rata Tes Awal

Dari tabel 4.5 diatas rata-rata

Hubungan Kemampuan

Menyususn Kalimat Efektif

Dengan Kemampuan Menulis

Wacana Eksposisi Siswa sesudah diberikan pembelajaran adalah sebesar 80,72 dan termasuk dalam kategori baik. Berdasarkan data nilai tes awal dan tes akhir siswa tersebut dapat diketahui bahwa ada Hubungan Kemampuan Menyususn Kalimat Efektif Dengan Kemampuan Menulis Wacana Eksposisi Siswa Kelas X SMA Negeri 1 Lawe Alas Tahun Pembelajaran 2016-2017.

b. Standar Devisiasi 
Dari table 4.5 diatas standar devisiasi

Hubungan

Kemampuan Menyususn

Kalimat Efektif Dengan

Kemampuan Menulis

Wacana Eksposisi Siswa

sesudah

diberikan

pembelajaran adalah sebesar

adalah 5,79

2. Menghitung Standar

Error dari Hasil Tes Awal dan Tes Akhir

Adapun

untuk

perhitungan standar error

tes awal dan tes akhir dari

Hubungan Kemampuan

Menyususn Kalimat

Efektif Dengan

Kemampuan Menulis

Wacana Eksposisi Siswa adalah sebagai berikut:
a. Standar Eror Tes Awal

Tabel 4.6 Standar Eror Tes Awal

Menulis Wacana Eksposisi oleh

\section{Siswa}

\begin{tabular}{|c|c|c|c|c|}
\hline & & Mea & $\begin{array}{c}\text { Std. } \\
\text { Deviati } \\
\text { on }\end{array}$ & $\begin{array}{c}\text { Std. } \\
\text { Error } \\
\text { Mean }\end{array}$ \\
\hline TES & 36 & 45.1 & 13.681 & 2.28029 \\
AW & & 944 & 73 & \\
AL & & & & \\
\hline
\end{tabular}

Sumber : Analisis Data dengan SPSS

19 for windows

Dari analisis data dengan spss 19 for windows dengan jumlah sampel 36 dan nilai rata-rata 45,19 di peroleh Standar error tes kemampuan awal menulis wacana eksposisi sebesar 2,28

b. Standar Eror Tes Akhir

Tabel 4.7 Standar Eror Tes Akhir

Menulis Wacana Eksposisi oleh

Siswa

\begin{tabular}{|l|c|c|c|c|}
\hline & N & $\begin{array}{c}\text { Mea } \\
\mathrm{n}\end{array}$ & $\begin{array}{c}\text { Std. } \\
\text { Deviati } \\
\text { on }\end{array}$ & $\begin{array}{c}\text { Std. } \\
\text { Error } \\
\text { Mean }\end{array}$ \\
\hline TES & 36 & 80.7 & 5.7946 & .96577 \\
AKH & & 222 & 3 & \\
IR & & & & \\
\hline
\end{tabular}

Dari analisis data dengan spss 19 for windows dengan jumlah sampel 36 dan nilai rata-rata 80,72 di peroleh Standar error tes kemampuan awal menulis wacana eksposisi

c. Perbedaan hasil standar eror dari tes awal dan tes akhir

Tabel 4.8 Standar Eror Tes Awal dan TesAkhir Menulis Wacana Eksposisi oleh Siswa 


\begin{tabular}{|c|c|c|c|c|}
\hline & & $\begin{array}{c}\text { Mtd. } \\
\text { Mea } \\
\mathrm{n}\end{array}$ & $\begin{array}{c}\text { Std. } \\
\text { Deviat } \\
\text { ion }\end{array}$ & $\begin{array}{c}\text { Error } \\
\text { Mean }\end{array}$ \\
\hline Nilai & 72 & 62.9 & 20.708 & 2.4404 \\
& & 583 & 19 & 8 \\
\hline
\end{tabular}

Sumber : Analisis Data dengan SPSS

19 for windows

Dari analisis data dengan spss 19 for windows peroleh Standar error tes kemampuan awal menulis wacana eksposisi sebesar 2,44

\section{Pengujian Hipotesis}

Adapun pengujian hipotesis statistikuntuk mengetahui Hubungan Kemampuan Menyususn Kalimat Efektif Dengan Kemampuan Menulis Wacana Eksposisi Siswa X SMA Negeri 1 Lawe Alas Tahun Pembelajaran 2016-2017 tersebut menggunakan uji t. uji t dilakukan dengan analisis spss 19 for windows. hasil analisis uji $\mathrm{t}$ menggunakan analisis spss 19 for windows dapat dilihat pada tabel berikut:

Tabel 4.7 Ringkasan Hasil Uji t Hubungan Kemampuan Menyususn Kalimat Efektif Dengan Kemampuan Menulis Wacana Eksposisi Oleh Siswa

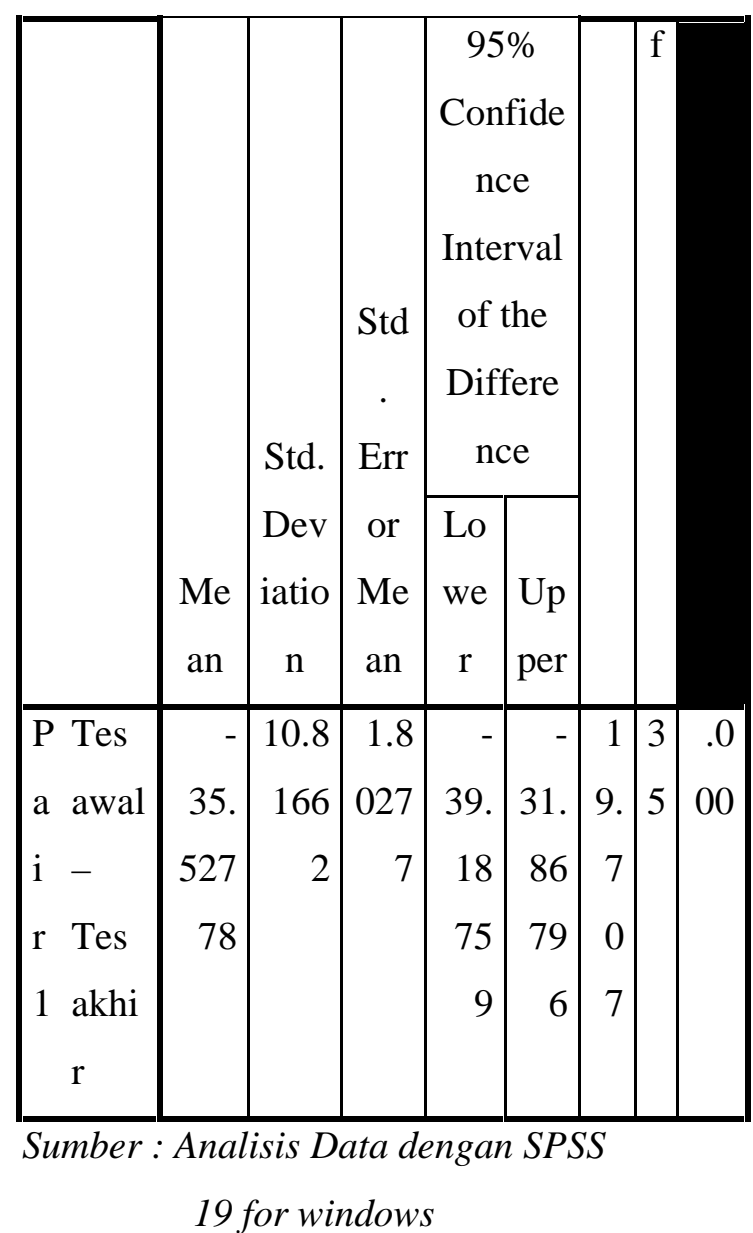

Dari tabel diatas diperoleh hasil $\quad t_{\text {hitung }}=19,70, \quad$ selanjutnya dikonsultasikan dengan nilai $t_{\text {tabel }}$ pada taraf signifikan $5 \%$ dengan $\mathrm{db}=$ $\mathrm{N}-1=36-1=35$, maka diperoleh nilai $\mathrm{t}_{\text {tabel }}=2,03$. Jadi dengan demikian nilai $t_{\text {hitung }} t_{\text {tabel }}$ atau diperoleh kesimpulan bahwa ada Hubungan Kemampuan Menyususn Kalimat Efektif Dengan \begin{tabular}{l|l|l|lll} 
Paired Differences & t & d & Sikemampuan Menulis Wacana
\end{tabular} Eksposisi Siswa Kelas X SMA 
Negeri 1 Lawe Alas Tahun

Pembelajaran 2016-2017.

Penelitian deskriptif

korelasional bertujuan untuk melihat hubungan antara dua gejala atau lebih, dan cocok dengan permasalahan. Berdasarkan hasil penelitian dan pembahasan yang telah diuraikan pada bab terdahulu maka dapat disimpulkan bahwa ada hubungan positif antara kemampuan menyusun kalimat efektif dengan kemampuan menulis wacana eksposisi siswa kelas X SMA Negeri 1 Lawe Alas Tahun Pembelajaran 2016-2017. Hal ini terbukti dari nilai rata-rata tes awal 45,19 dan termasuk dalam kategori kurang, standar deviasi hubungan positif antara kemampuan menyusun kalimat efektif dengan kemampuan menulis wacana eksposisi siswa sebelum diberikan pembelajaran 13,68 dan mengalami peningkatan nilai hasil tes akhir sesudah diberikan pembelajaran adalah sebesar 80,72 dantermasuk dalam kategori baik.

Selain itu, dari tabel diatas diperoleh hasil $t_{\text {hitung }}=19,70$, selanjutnya dikonsultasikan dengan nilai $t_{\text {tabel }}$ pada taraf signifikan $5 \%$ dengan $d b=\mathrm{N}-1=36-1=35$, maka diperoleh nilai $t_{\text {tabel }}=2,03$. Jadi dengan demikian nilai $t_{\text {hitung }} t_{\text {tabel }}$ atau diperoleh kesimpulan bahwa ada Hubungan Kemampuan Menyususn Kalimat Efektif Dengan Kemampuan Menulis Wacana Eksposisi Siswa Kelas X SMA Negeri 1 Lawe Alas Tahun Pembelajaran 2016-2017.

\section{DAFTAR PUSTAKA}

Arikunto, Suharsimi. 2006. Prosedur Penelitian Suatu Pendekatan Praktik. Jakarta :Rineka Cipta

Abdul Rozak.1990. Kalimat efektif: Struktur, Gaya, dan Variasi. Jakarta: Gramedia Pustaka Utama

Darmadi, Kaswan. 1996. Meningkatkan Kemampuan Menulis Panduan untuk Mahasiswa dan Calon Guru. Yogyakarta: Andi

Depdiknas. 1991. Kamus Besar Bahasa Indonesia. Jakarta: Balai Pustaka . 2006. Kurikulum Tingkat

Satuan Pendidikan (KTSP).

Jakarta:Departemen

Pendidikan Nasional. Dimyati dan Mujiono. 
Gorys Keraf. 2001. Komposisi. Ende Flores: Nusa Indah.

Semi, M. Atar. 1990. Menulis Efektif. Padang: Angkasa Raya

Semi, Atar. 2007. Dasar-dasar keterampilan menulis. Bandung: Angkasa

Sugiyono. 2006. Metode Penelitian Pendidikan. Bandung: Alfabet

Syafie'ie, Imam. 1988. Retorika dalam Menulis. Jakarta: P2LPTK Depdikbud

Tarigan. 1994. Menulis Sebagai Suatu Keterampilan Berbahasa. Bandung: Angkasa.

Tarigan, Henry Guntur. 2008. Menulis Sebagai Suatu Keterampilan Berbahasa. Bandung: Angkasa. 